\title{
COMPUTER CONSTRUCTION, MODELING AND FABRICATION OF CORSET
}

\author{
Maja Jankoska ${ }^{1}$, Ekaterina Petreska ${ }^{1}$ \\ 1 University "Ss. Cyril and Methodius" in Skopje, Faculty of Technology and Metallurgy, \\ Department of Textile Engineering, North Macedonia \\ * e-mail: maja@tmf.ukim.edu.mk \\ Stručni rad \\ UDC: $687.1 / 4$ \\ doi: $10.5937 /$ tekstind1904011J
}

\begin{abstract}
The aim of this paper is to make a computer construction, modeling, grading and marker from a technical sketch and finalized with the fabrication work of the test model of the pleated corset. The basic dress pattern was used for modeling a corset. On the constructed basic pattern of the front and back part of a dress, modeling procedures were applied for the purpose of developing the finished pattern of a plated princess corset. For the purpose of correctness controle and the quality of modeling of the garment, a test model of corset was made according to the measures, testing the success of designing and modeling. The test model was tested and the corset fit was assessed. With technology development, computer construction and modeling of the corsets the procedure of producing corsets is faster than traditional procedure, whereby we get important time saving and precision of the patterns and we can faster see the mistakes and fix them, also, the grading of a certain model is faster and more precise. Planning and forming of the marker are shown in a few steps for getting the marker.
\end{abstract}

Key words: CAD-systems, corset, construction, modeling, marker.

\section{KOMPJUTERSKA KONSTRUKCIJA, MODELOVANJE I IZRADA KORSETA}

Apstrakt: Cilj ovog rada je da se od tehničke skice naprave kompjuterska konstrukcija, modelovanje, gradiranje i krojne slike uz izradu probnog modela korseta s faltama. Osnovni uzorak haljine korišćen je za modelovanje korseta. Na konstruiranom osnovnom kroju prednjeg i zadnjeg dela haljine primenjeni su postupci modelovanja u svrhu razvoja gotovog uzorka korseta s faltama. U cilju kontrole ispravnosti i kvaliteta modelovanja odeće, napravljen je probni model korseta prema merama, testirajući uspeh dizajniranja i modelovanja. Probni model je testiran i procenjena je pristalost. Sa razvojem tehnologije, kompjuterskom konstrukcijom i modelovanjem korseta postupak izrade korseta je brži od tradicionalnog postupka, pri čemu dobijamo važnu uštedu vremena i preciznost konstruiranja i brže možemo videti greške i ispraviti ih, takođe, gradiranje određenog modela je brže i preciznije. Planiranje i oblikovanje prilagođene krojne slike prikazano je u nekoliko koraka za dobijanje krojene slike.

Ključne reči: CAD-sistemi, korset, konstrukcija, modelovanje, krojna slika.

\section{INTRODUCTION}

The desire and the need to emphasize the narrow waist led to the emergence of the most controversial clothing item in fashion history, the famous corset. The word corsage comes from the old-french word "cors" which diminishes body words and "corset" is a term related to the lower garment that strengthens the body by enhancing the waist and breast, and depending on the time it was worn, it also included the hips [1]. A corset is a garment worn to hold and train the torso into a desired shape, traditionally a smaller waist or larger bottom, for aesthetic or medical pur- 
poses (either for the duration of wearing it or with a more lasting effect), to improve posture [2], or support the breasts. The corset has been an important article of clothing for several centuries in Europe, evolving as fashion trends have changed. Women, as well as some men, have used it to change the appearance of their bodies [1]. Corset article of clothing worn to shape or constrict the waist and support the bosom, whether as a foundation garment or as outer decoration. During the early eras of corsetry, corsets-called stays before the 19th century and made stiff with heavy boning-molded a woman's upper body into a $\mathrm{V}$-shape and flattened and pushed up the breasts. Some were attached to petticoats or could be fastened to them to preserve a flat shape at the waist. Young children were also often fitted with corsets or stays to ensure straight spines and pleasing body shapes later in life. Later, as fashions changed, corsets became more hourglass-shaped to emphasize the female figure [3].

The first evidence of corset like garments can be found in the art of the Minoan civilization, which depicts women wearing metal plates that slim the waist and accentuate the bust. Waist-shaping garments appeared sporadically in Europe during the middle Ages, worn by members of both sexes. About the 15th century women began to wear bodices stiffened with paste, known then as a pair of body's. In the 16th century that type of bodice became a separate article of underclothing, laced together either in front or in back and eventually supported throughout with strips of a firm material-such as wood, bone, or horn-between two layers of fabric. Corsets that were laced up the front were often covered by a decorated panel known as a stomacher that concealed the laces. The corset of 16th-century Spain was supported in the front by a vertically placed wooden or bone rod (or two, if the garment laced in the front) known as a busk, which produced a flat shape, and was reinforced elsewhere with whalebone stays. The busk became a predominant feature of later corsets, despite other changes [3]. Corsets are typically constructed of a flexible material (like cloth, particularly coutil, or leather) stiffened with boning (also called ribs or stays) inserted into channels in the cloth or leather. In the 18th and early 19th century, thin strips of baleen (also known as whalebone) were favored for the boning $[4,5]$. Summers [6] indicated that corsetry operated as a powerful and multi-faceted signifier of both transgressive and normative femininity in different contexts. As stated in The Corset in Late 20th Century Fashion, fashion designer Vivienne Westwood used corsets in their original forms but applied them to contemporary fashion [7].
During the 20th century the corset was gradually replaced as everyday wear by the brassiere and girdle, but it remained in use in bridal fashions and costume wear into the 21st century. Corsets and corset-style tops without structural supports retained an amount of popularity as outerwear, especially in alternative fashion, and were sometimes featured in the works of respected fashion designers. Tightly laced corsets also remained popular among those engaged in certain forms of body modification. Markić et al. [8] describes the design and modeling of corset dating from around 1880.

Today, CAD systems are increasingly being used for construction, modeling, grading and marker creation. Antic et al. [9] present the computer method of pattern cutting images fitting using CAD system of construction preparation in clothing industry based on defined parameters in man's jacket making.

This aim of this paper is to make a computer construction, modeling, grading and make marker and fabrication test model plated corset from a technical sketch.

\section{EXPERIMENTAL PART}

Figure 1 shows a technical sketch of the corset model from which the computer construction, modeling, grading, marker and fabrication of the test model was made.

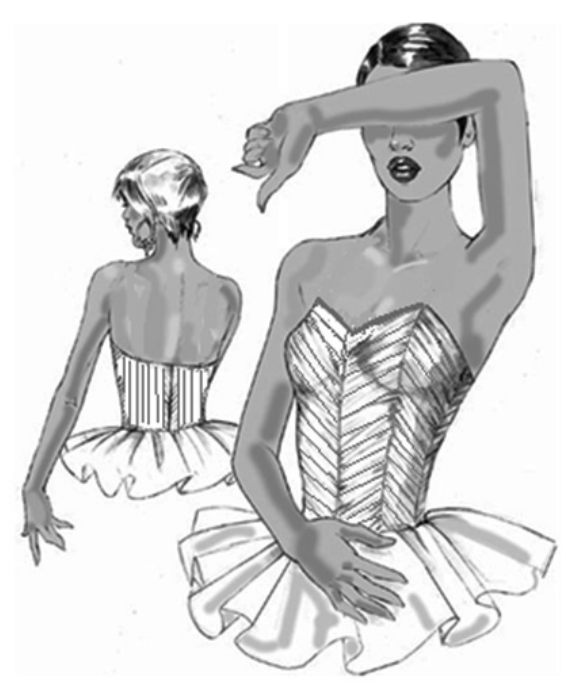

Figure 1: Technical sketch of women`s corset

The strapless corset has a gathered front panel shirred on an angle indicating added fullness (parallel openings) and is an application of added fullness combined with contouring. The back can be with or without gathers, but here is shown a back with gathers (added fullness). 
The basic design of the dress with the computer program Gerber was constructed made on the previously calculated measures required for the construction and application to the corresponding functions in the CAD system. The basic dress pattern was used for modeling a corset. On the computer constructed a basic pattern of the front and back part of dress modeling procedures were applied to develop the finishing pattern of a corset. Also, are made the computer grading, table of model and markers to finally fabrication the designed model to the platted corset. The front of the corset is made of four parts and back made of two parts. The whole corset is in pleats. Corset is fastened to the back with 7 buttons. The fabrication test model visually reveals the quality of the construction and the modeling of the corset model, because only a tailor-made well adapted to the body and adequate wearing comfort ensures the aesthetics and functionality of the product.

\subsection{Computer construction on the basic pattern of the dress}

The construction of a basic pattern of the dress is made with pre-calculated necessary measures without additions for comfort for size M. Figure 2 shows the computer construction of the basic dress pattern. To rationalize the construction, the base cut was taken up to the height of hips, which is a measure of the height of hips taken as the length of the dress. The necessary functions were used to construct an appropriate computer program.

\subsection{Preparing a basic pattern for corset modeling}

Preparing for corset modeling (front and back) is shown in figure 3. Close the chest dart and open the lower dart on the waist. After that, from the center bust point according to the front center line a dart opening about $3 \mathrm{~cm}$ or less and later this dart closes when the contours for that part are drawn and shaped with a curve to give a good chest basket shape. The front side length is subtracted and lower by $1,0 \mathrm{~cm}$. The center front length is $22 \mathrm{~cm}$. The contours for the second front part are drawn and additional shaping is made for a better look, as shown in fig. 3. Two parts on the front are obtained.

The back side length subtracted and lower of $1,0 \mathrm{~cm}$ as on the front and also subtracted at the waist by side $1,5 \mathrm{~cm}$ because on the dart of waist decrease to $1.5 \mathrm{~cm}$. This is done to get a better shape and fit the back. The desired height of the corset on the center back is determined by $18 \mathrm{~cm}$. The length of the side of the corset is $20 \mathrm{~cm}$. A slight curve connects the side part with the center back. The contours of the corset on the back are also drawn and the dart between the two parts is closed and one part on the back is obtained. The molded parts (front and back) thus obtained are also used for basic lining parts.

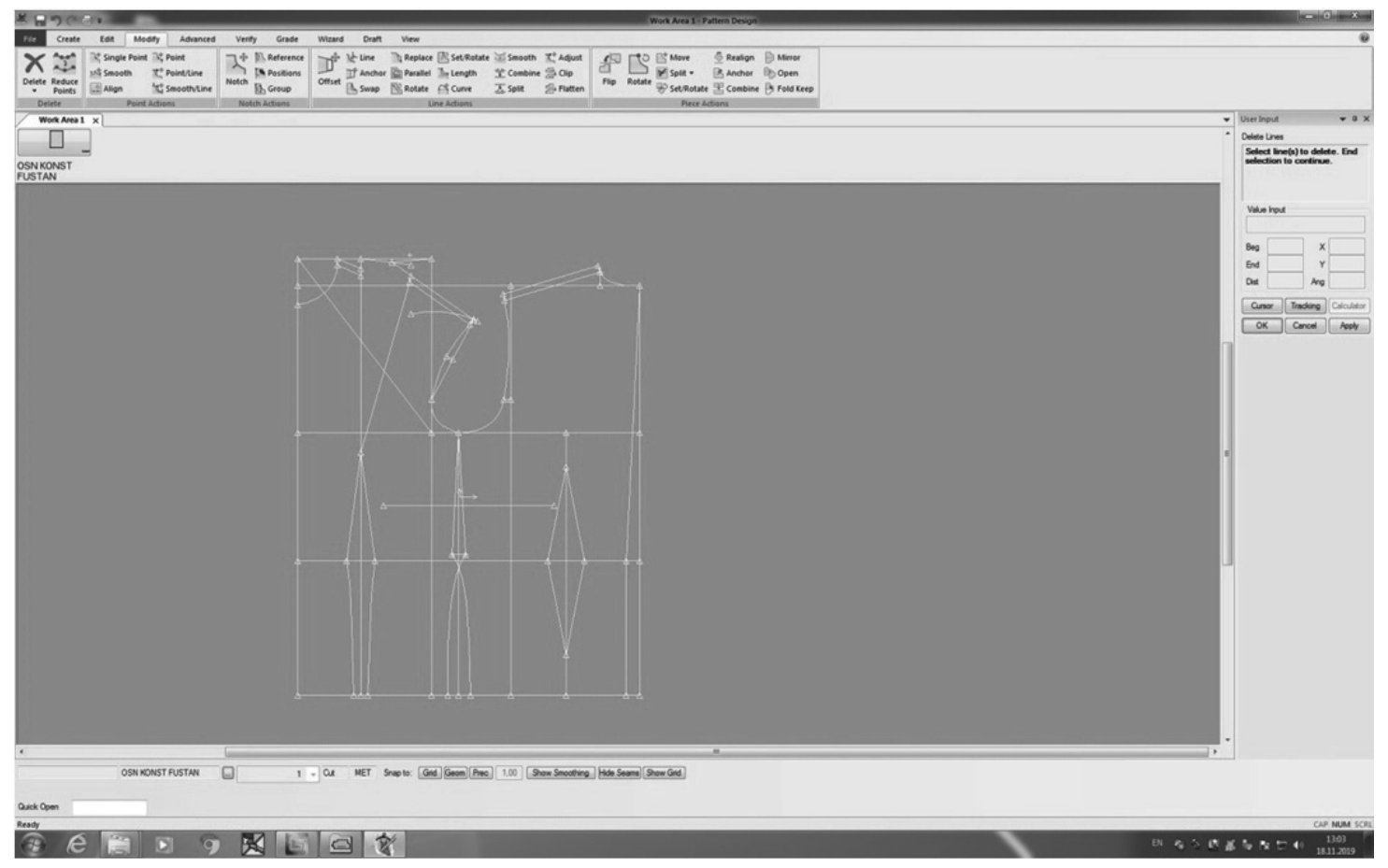

Figure 2: Construction on the basic pattern of the dress 


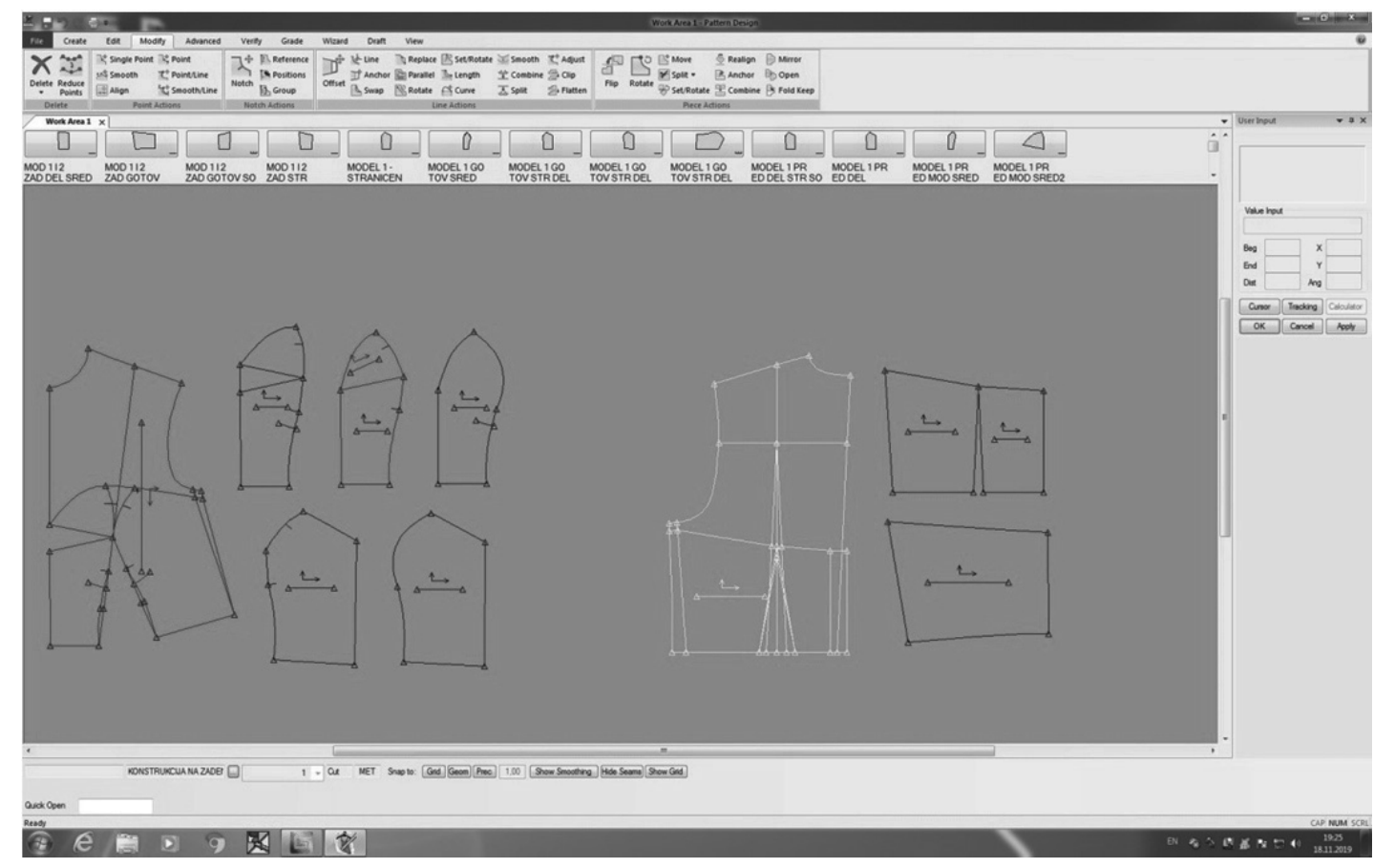

Figure 3: Preparing a basic pattern of dress to modeling the corset

\subsection{Modeling the front and back part the model of corset}

The modeling of the corset (front and back) is shown in figure 4. Modeling the plated of corset implemented as follows steps:

- Draw a vertical guideline.

- Cut through each section of the pattern.

- Align the grainline with the vertical guideline.
- Spread each section $2,5 \mathrm{~cm}$ (can be more or less) and secure.

- Trace the outline of the pattern and mark the corners of each section.

- The guideline is the straight grain, or a bias grain line can be drawn. Trim $0,5 \mathrm{~cm}$ from princess seam lines if bias grainline is used.

The same procedure is followed for a gathered back.

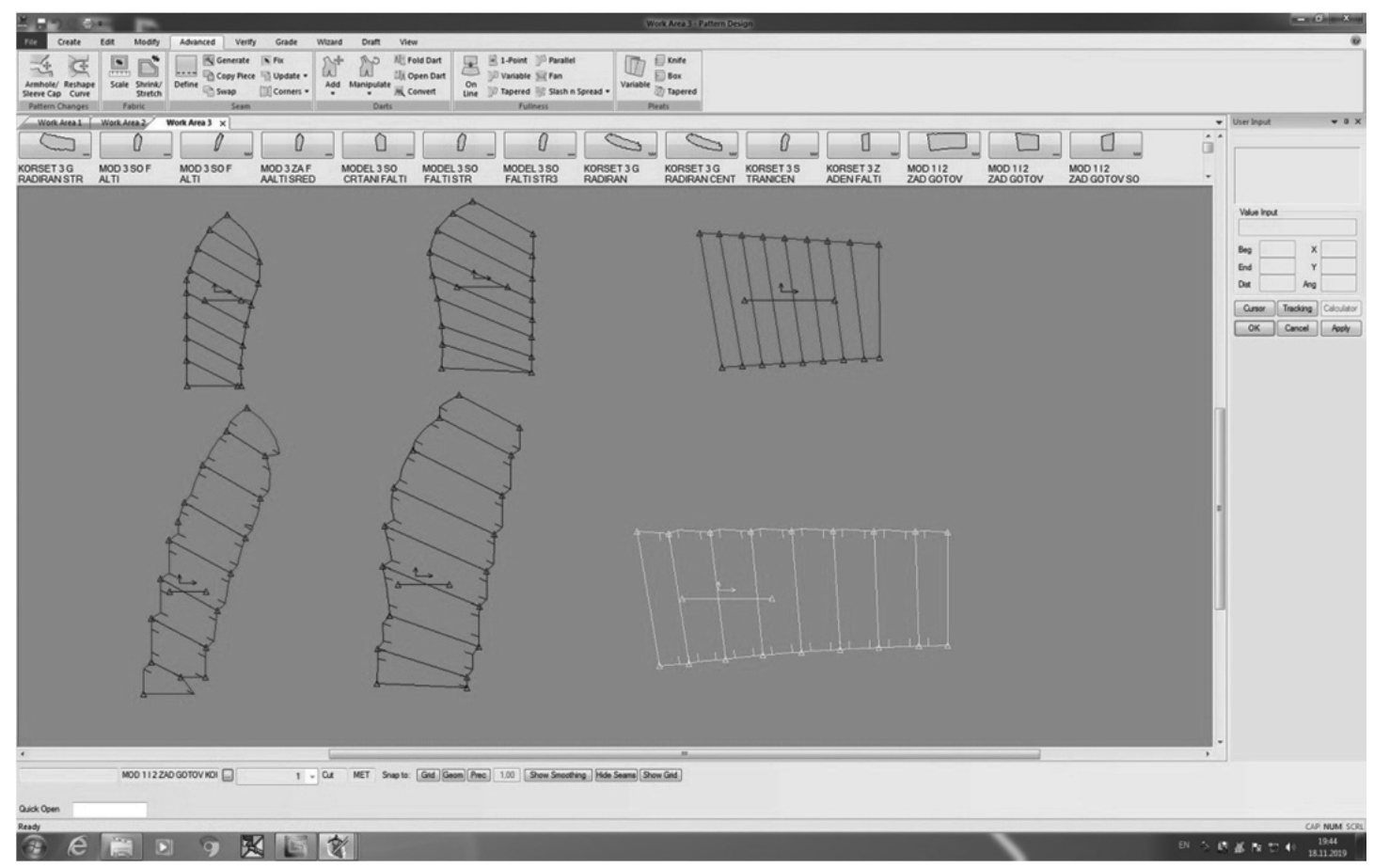

Figure 4: Modeling front and back of the model corset 
The gathered panels are stitched to the backing panels, and they are stitched together. The lining is stitched and joined to the backing.

The basic pattern parts of the basic fabric are used as the basis for the construction of the lining, while the contours of the lining parts are retained by the contours of the lining parts of the basic fabric.

After modeling the front and back of the corset, seams of $1 \mathrm{~cm}$ on all sides are added to the pattern pieces and pieces of the lining (fig. 5 and 6).

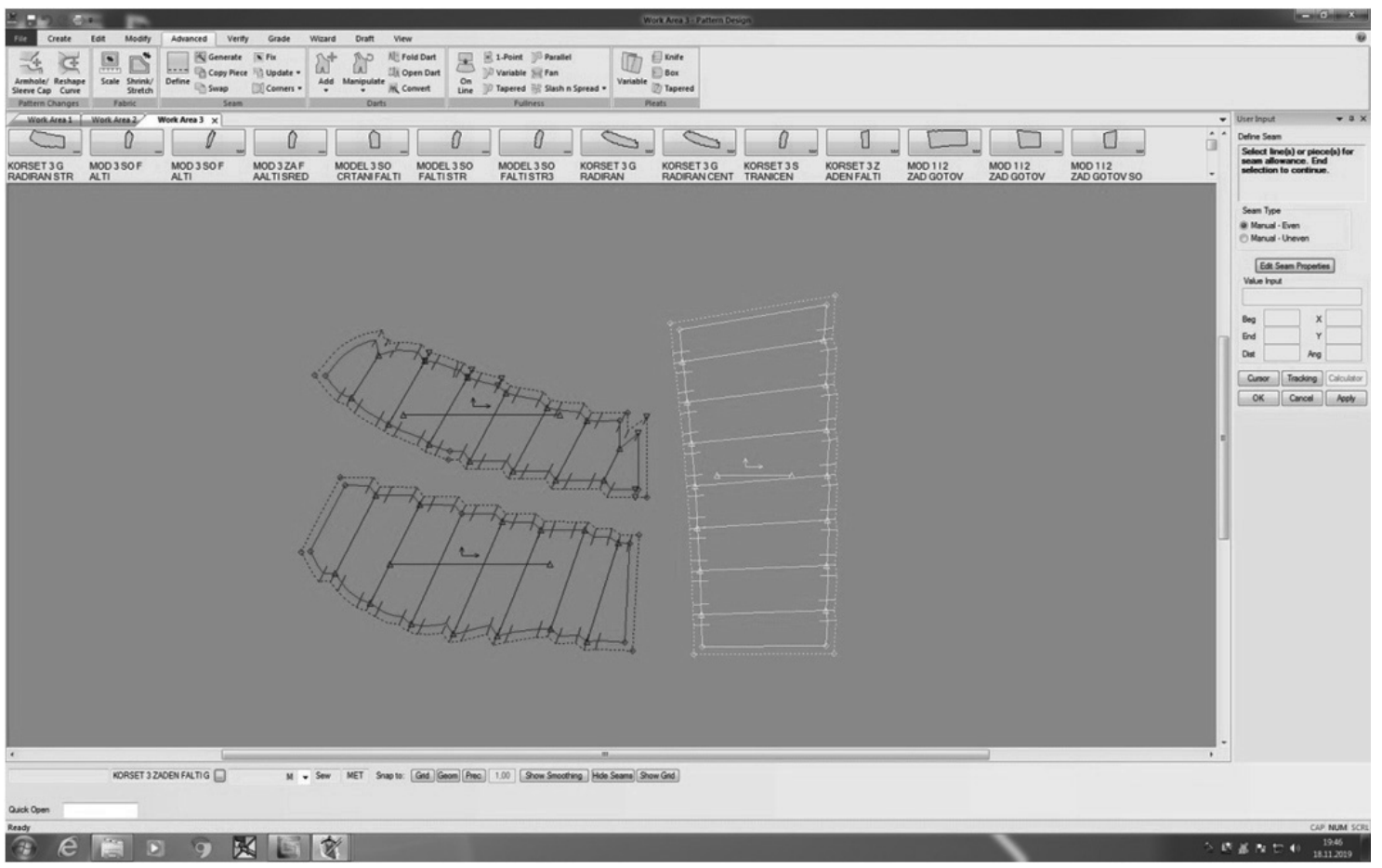

Figure 5: Adding a seam allowance to the front and back of the corset

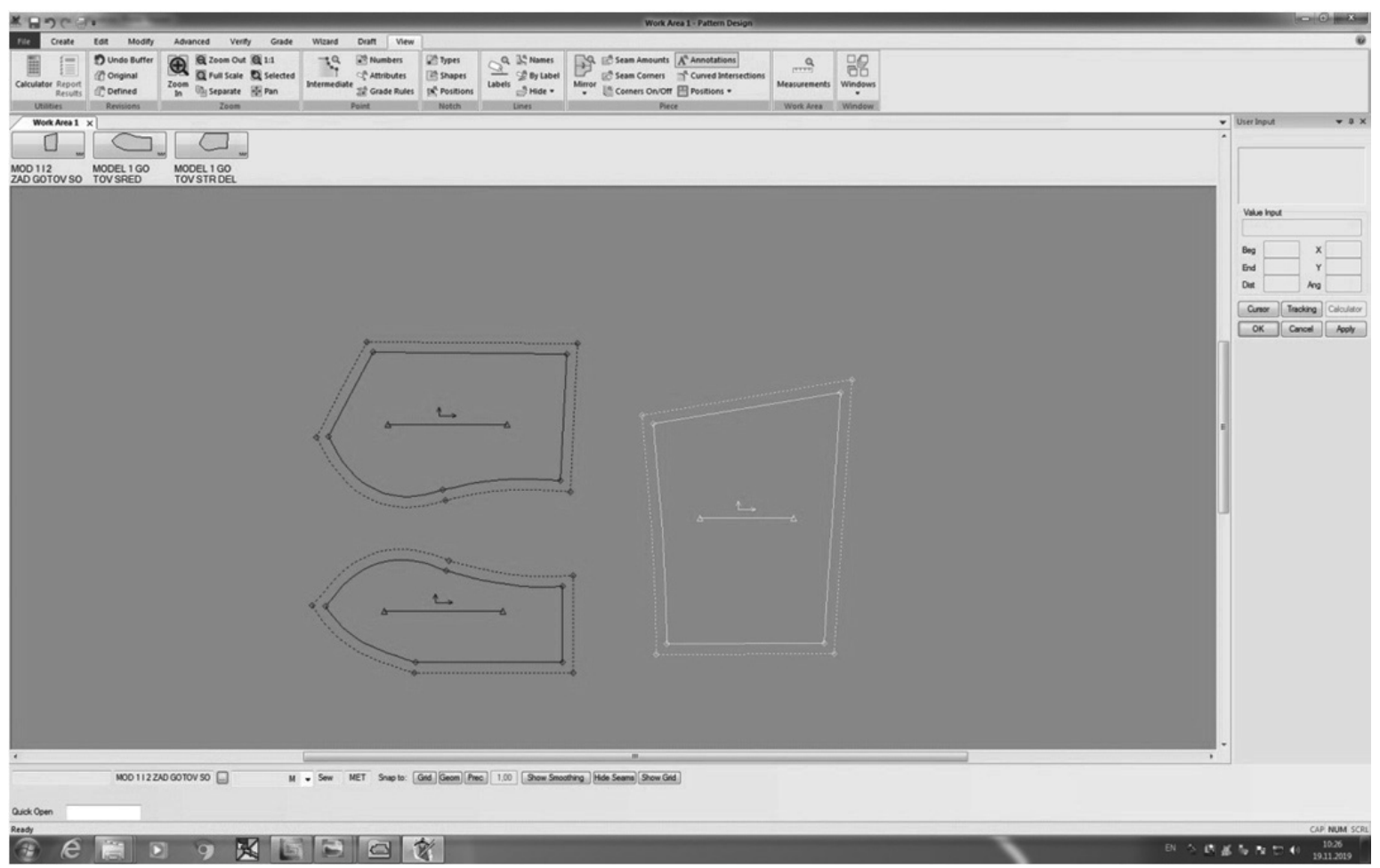

Figure 6: Adding a seam allowance to the lining of the corset 


\subsection{Grading front and back part, and lining of a model to the corset}

Figure 7 shows a grading of the front and back on the basic material of a corset.

Figure 8 shows the grading of the lining of the model of a corset. Computer grading is made on sizes $\mathrm{XS}, \mathrm{S}, \mathrm{M}, \mathrm{L}$ and $\mathrm{XL}$.

\subsection{Creating a Marker}

To generate a Marker there have to be several Rule Tables, and they are:

- Block buffer is a table where you can fulfill the add around (block) or the space between patterns (buffer) in the marker.

- Annotation table is defined by creating lines and text in the Marker.

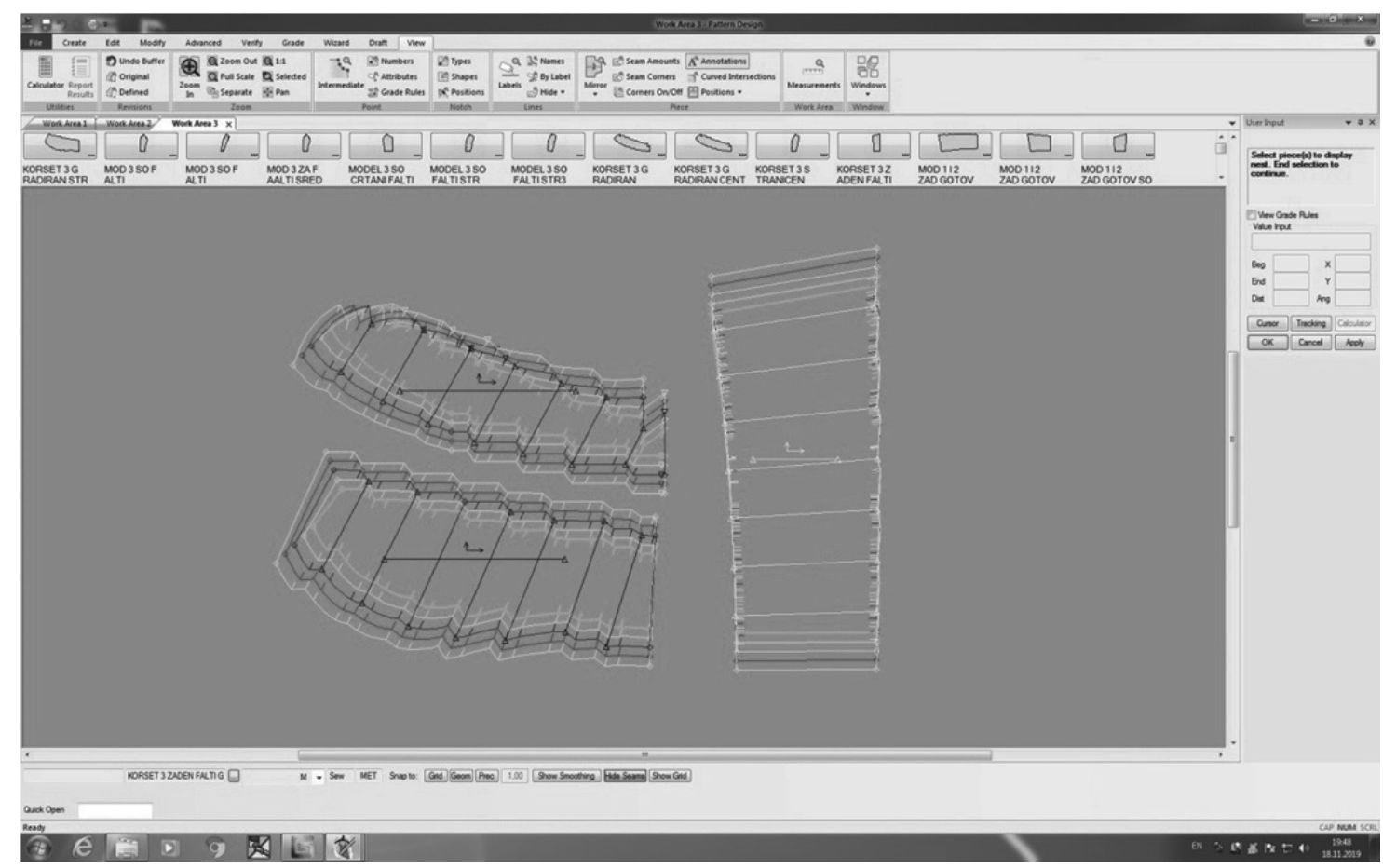

Figure 7: Grading of basic materials for a corset (front and back part)

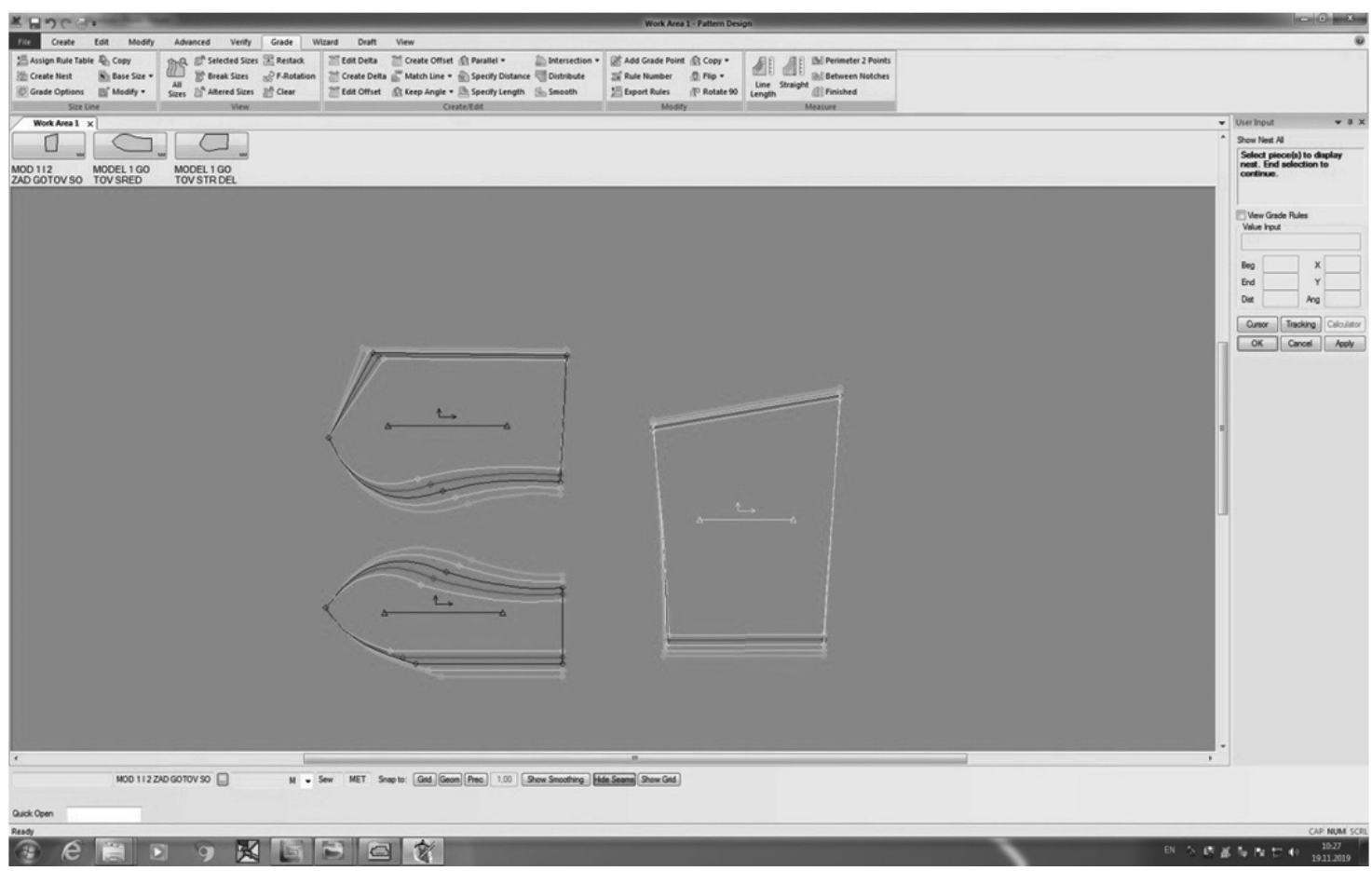

Figure 8: Grading of lining for a corset 
- $\quad$ Lay Limits Table is defined by the type of the fabric spread, the direction of cutting sizes into the Marker if there is any rotation in the Marker in order of the original part.

- $\quad$ Notch Table is a defined type of notch.

Two Model tables were created for the base material and the lining (fig. 9 and fig.11) and two markers (fig. 10 and fig. 12).
It is also necessary to select the appropriate fabric for the particular model to fit well on the body. After the marker for the base material and the lining is made, cutting is started on all parts of the corset model. Subsequently, the test model corset is sewing. The base material and lining are sewn separately and later combined to obtain the required corset model, which is shown as a finished product in Figure 13. The sew-

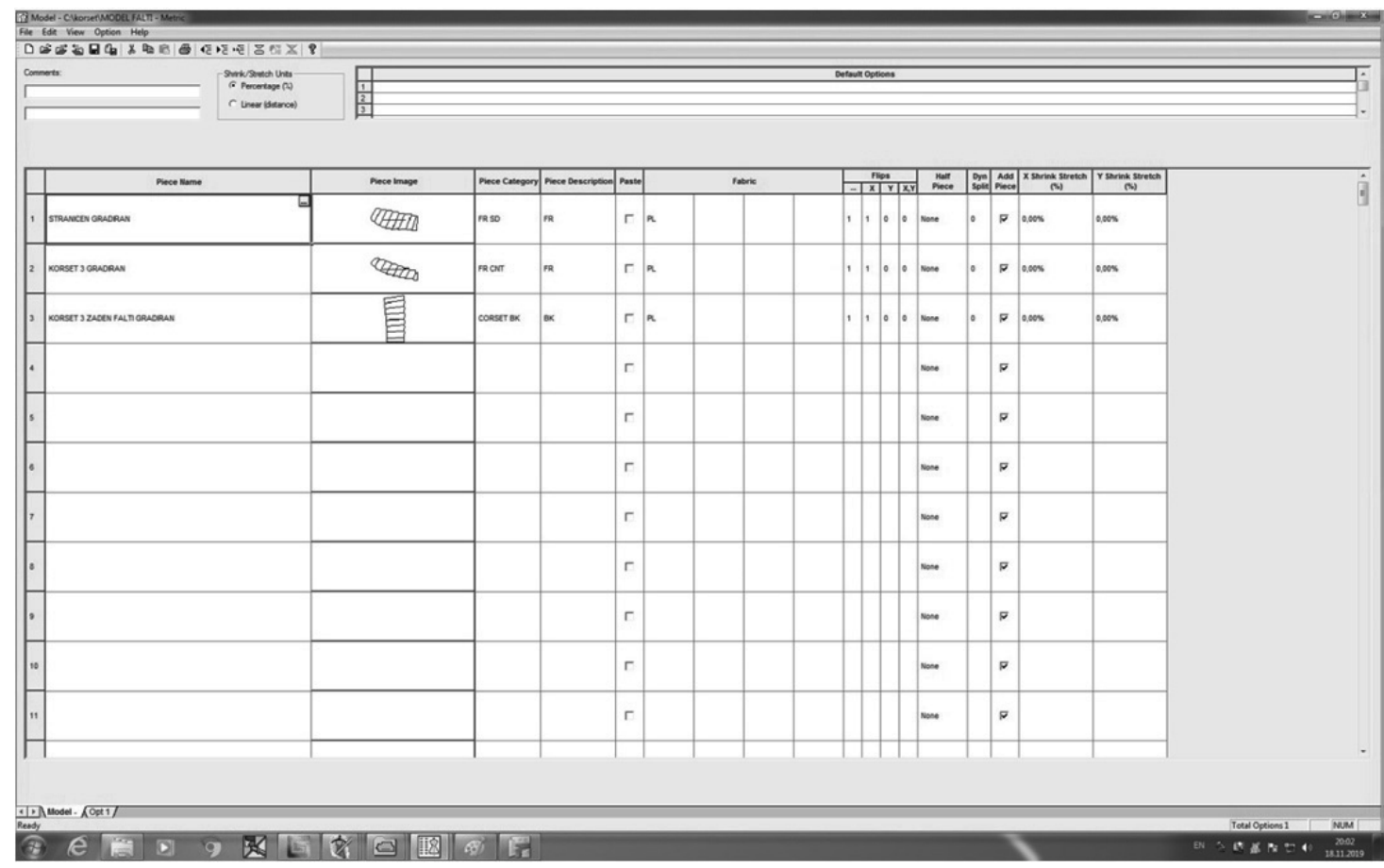

Figure 9: Table of Model for basic material of the corset

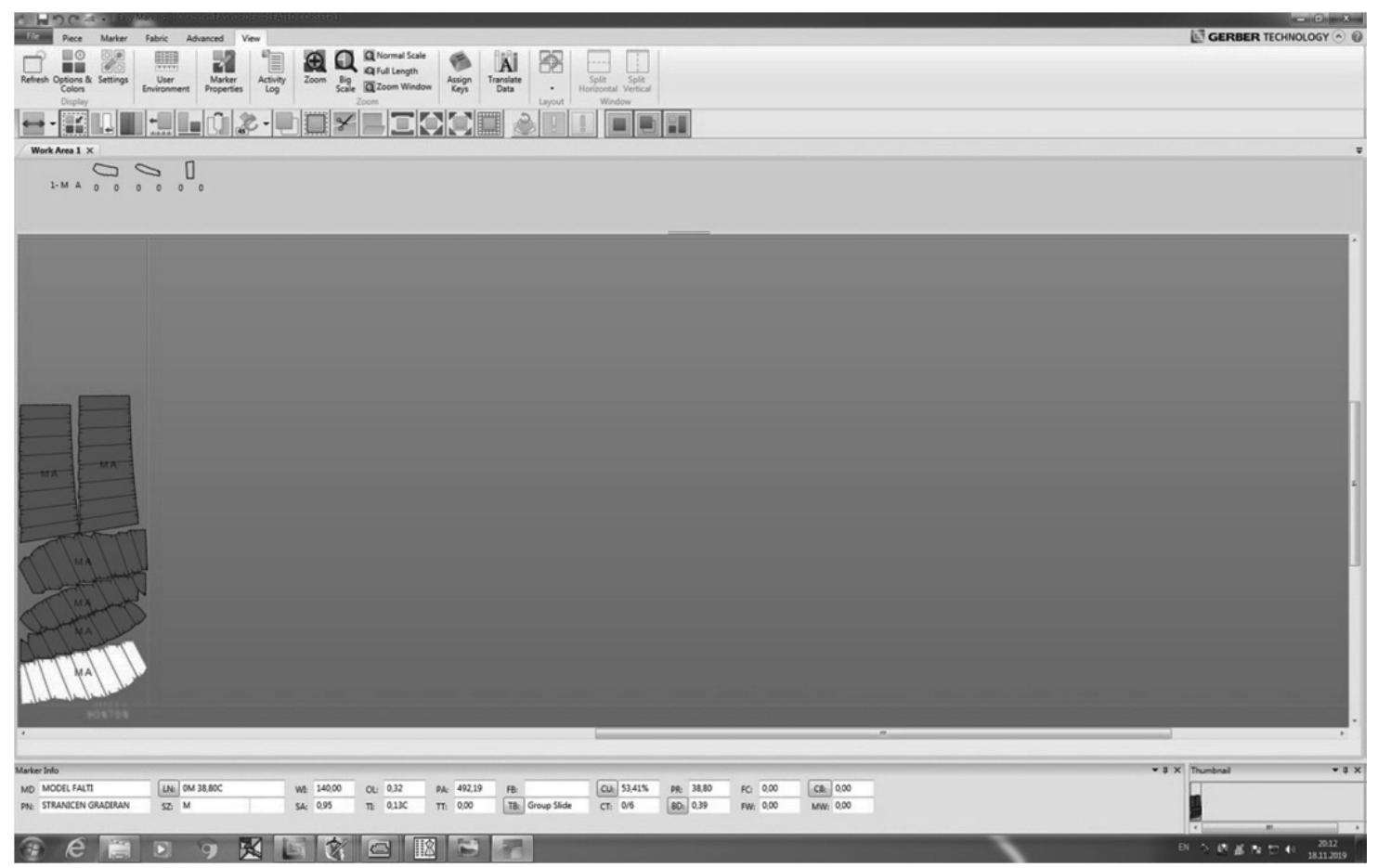

Figure 10: Marker for size $M$ (front and back) basic material of the corset 
ing model shows whether the corset is good fitting or where we need corrections. For the fabrication of the test model were used different sewing machines.

In this way, the model of the corset with pleated was created from idea to realization, with the help of a computer program that facilitates the whole work compared to the manual construction, and where it can be faster and easier to see and remove errors and deficiencies in the model.

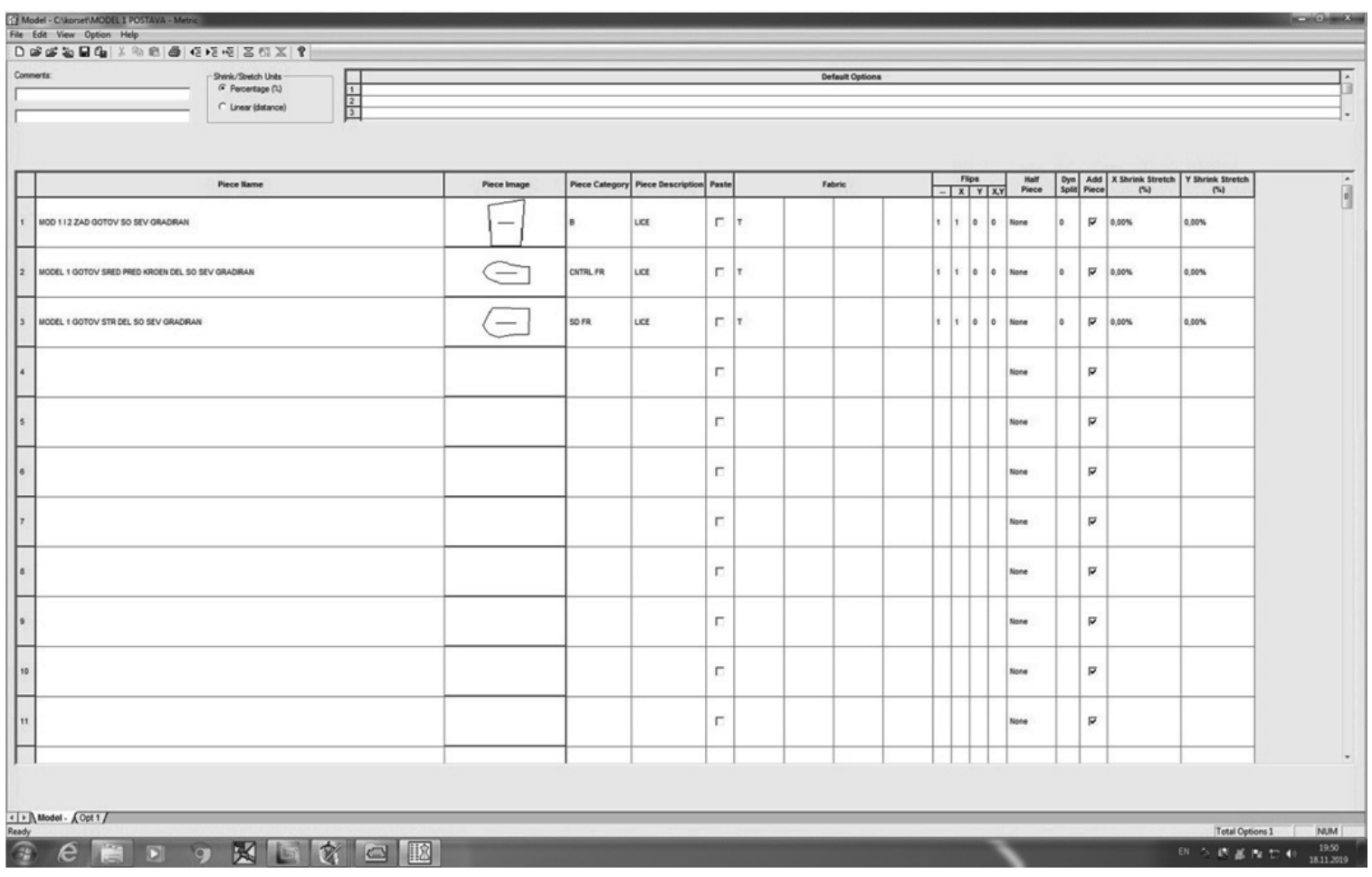

Figure 11: Table of Model for lining of the corset

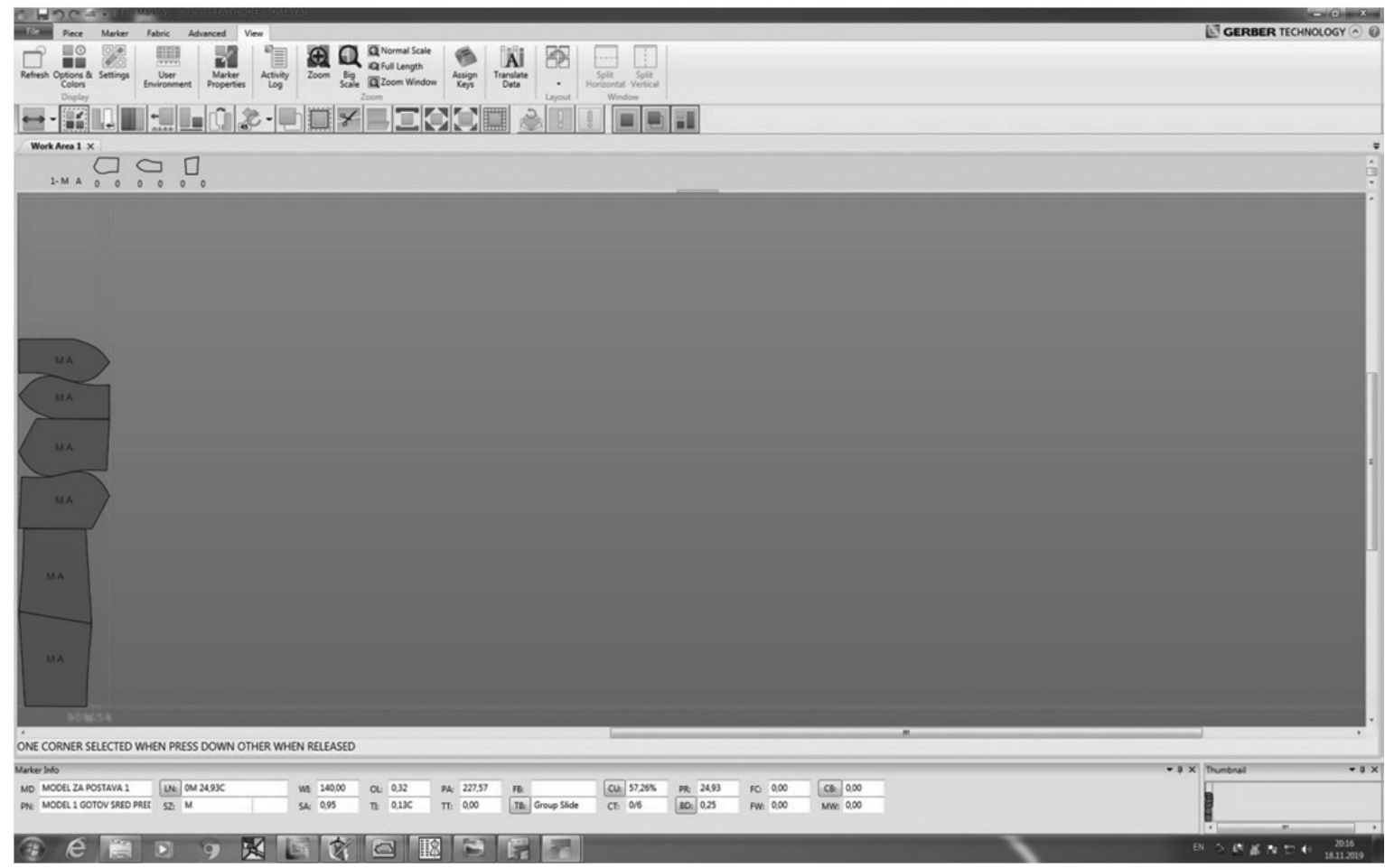

Figure 12: Marker of lining for size $M$ of the corset 


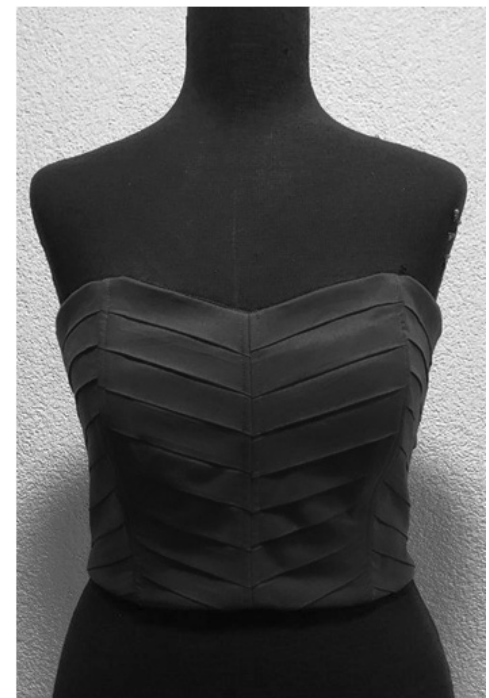

a) Front

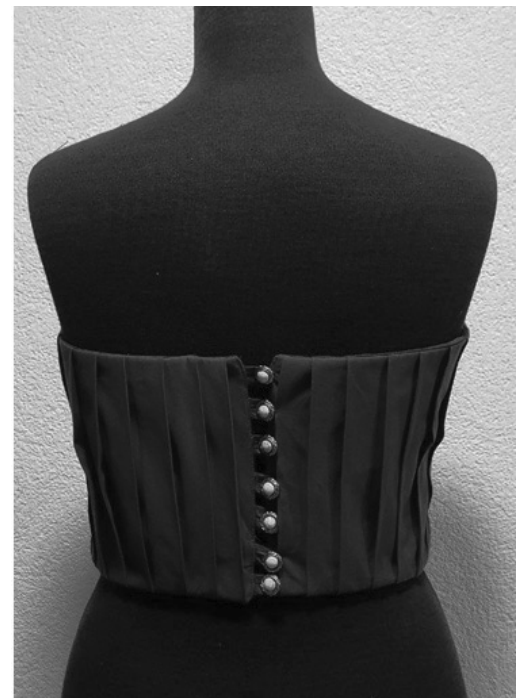

b) Back

Figure 13: Fabricated the model of a corset with pleated

\section{CONCLUSION}

Making a corset requires considerable technical skills and knowledge of the anatomy of the body to design a well-fitting corset. The introductory part gives an overview of the development of corsets and the application of CAD-systems. The experimental part defines the measures needed to create the basic pattern and computer construction of the basic design of the dress with AccuMark Gerber Technology. On the constructed basic pattern of the front and back of the dress, modeling procedures were applied in order to develop the finished model of the corset with pleated. The model also has a lining where its construction is made. Subsequently, grading of the base material and lining were done. A base material model and a lining have also been created to give us the opportunity to form markers. Then a corset model is cut out with a marker. In order to control the correctness and quality of the computer-aided modeling of the garment, a trial model of the corset was realized, as well as tested on the body. Different sewing machines were used for the fabrication of the test model. Using the CAD system is obtained more easily and quickly from idea to realization of the desired model.

\section{REFERENCES}

[1] https://en.wikipedia.org.wiki/Corset, available: (11.11.2019).

[2] Evolution of Corsets Throughput History, Corset Center.com. 2014-04-03., available: (11.11.2019.)
[3] https://www. encyclopediabritannica.com/topic/ corset, available: (11.11.2019).

[4] Doyle, R. (1997). Waisted Efforts: An Illustrated Guide to Corset Making, Sartorial Press Publications.

[5] Waugh, N. (1990). Corsets and Crinolines, Routledge.

[6] Summers Leigh. (2001). Bound to Please, Oxford: Berg.

[7] Erkal, M.M. (2017).The Cultural History of the Corset and Gendered Body in Social and Literary Landscapes, European Journal of Language and Literature Studies, 3(3),109-118.

[8] Markić, M., Domjanić J.,Ujević D. (2017). Konstrukcija, modeliranje i izrada korzeta, Tekstil, 66(9/10), 255-264.

[9] Antić, S., Ilić, A., Đorđević, S., Petrović, D. (2018). Analiza uticaja definisanih parametara BlokBafer-a pri izradi krojnih slika računarom, Tekstilna industrija, 66(4), 45-51.

Rad primljen: 22.10.2019.

Rad prihvaćen: 30.11.2019. 